\title{
Long Term Study of Protective Mechanisms of Human Adipose Derived Mesenchymal Stem Cells on Cisplatin Induced Kidney injury in Sprague-Dawley Rats
}

\author{
Elhusseini FM ${ }^{1,5}$, Saad M-AAA ${ }^{2,5}$, Anber $N^{3}$, Elghannam D ${ }^{4}$, Sobh M-A ${ }^{5 a}$, Alsaied A ${ }^{6}$, El-dusoky $\mathrm{S}^{6}$, Sheashaa $\mathrm{H}^{5 b}$, \\ Abdel-Ghaffar $\mathrm{H}^{4}$, Sobh $\mathrm{MA}^{5 \mathrm{~b}, 6}$
}

Background/Aims: Long-term evaluation of cisplatin induced nephrotoxicity and the probable renal protective activities of stem cells are lacking up until now. We evaluated the early and long-term role of human adipose derived mesenchymal stem cells (ADMSCs) in prevention or amelioration of cisplatin induced acute kidney injury (AKI) in Sprague-Dawley rats. For this, we determined the kidney tissue level of oxidative stress markers in conjugation with a renal histopathological scoring system of both acute and chronic renal changes.

Methods: This study used eighty Sprague-Dawley (SD) rats weighing 250-300g. They were assigned into four equal groups (each group $\mathrm{n}=20$ ): (I) Negative control group, rats injected with single dose of $1 \mathrm{ml}$ normal saline. (II) Positive control cisplatin, rats injected with a single dose of $5 \mathrm{mg} / \mathrm{kg}$ I.P in $1 \mathrm{ml}$ saline. (III) Cisplatin and culture media group, rats injected with $0.5 \mathrm{ml}$ of culture media single dose into the tail vein and (IV) Cisplatin and ADMSCs group, rats injected with a single dose of $0.5 \mathrm{ml}$ of culture media containing $5 \times 10^{6}$ ADMSCs into the tail vein one day after cisplatin administration. Each main group was further divided according to the timing of sacrifice into four subgroups (each subgroup $n=5$ ). Rats in the subgroup A were sacrificed after 4 days; subgroup B were sacrificed after 7 days; subgroup C were sacrificed after 11 days; and subgroup D were sacrificed after 30 days. Before sacrifice, 24 hrs.-urine was collected using a metabolic cage. Renal function was evaluated through blood urea nitrogen $(\mathrm{BUN})$, serum creatinine and creatinine clearance. Kidney tissue homogenate oxidative stress parameters, Malondialdehyde (MDA), Superoxide dismutase (SOD) and Glutathione (GSH) were determined. In addition, histopathological analysis for active injury, regenerative and chronic changes was performed.

Results: ADMSCs were characterized and their capability of differentiation was proved. Cisplatin induced a significant increase in plasma creatinine and tissue MDA and induced a decrease in SOD, GSH and creatinine clearance. ADMSCs attenuated these changes. Cisplatin resulted in prominent histopathological changes in the term of tubular necrosis, atrophy, inflammatory cells infiltration and fibrosis. ADMSCs significantly lowered the injury score at day 4, 7, 11 and 30 with marked regenerative changes starting from day 4 and limited fibrotic score at day 30.

Conclusion: ADMSCs have both protective and regenerative abilities with consequent limitation of the development of renal fibrosis after the cisplatin induced acute tubular necrosis, largely through an anti-oxidative activity.

Key Words: Acute kidney injury in rats, Renal fibrosis, Cisplatin, Adipose mesenchymal stem cells, Oxidative stress markers.

\section{Introduction}

Cisplatin is a chemotherapeutic agent largely used for the treatment of many human malignancies. However, nephrotoxicity is one of the serious adverse effects that limit its clinical use. Cisplatin has multiple cellular targets; so blocking its effect on a single target may only offer moderate protection against nephrotoxicity ${ }^{[1]}$. Hence, to alleviate cisplatin nephrotoxicity a strategy to tackling multiple cellular levels is important. Several potential advantages through cell therapy over specific drugs or growth factors in the treatment of many disorders as AKI have been demonstrated ${ }^{[2,3]}$.

Mesenchymal stem cells (MSCs) are multi-potent adult stem cells harbouring multi lineage differentiation potential, paracrine and immunosuppressive properties that make MSCs an ideal candidate cell type for immunomodulation and regeneration ${ }^{[4]}$.

Adipose tissue contains different cell types besides adipocytes, including adipose derived mesenchymal stem cells (ADMSCs), which are emerging as cellular therapy tools ${ }^{[5]}$.
Plasticity of ADMSCs and their capability of differentiation into cells of mesodermal origin, such as adipocyte, osteocyte, chondrocyte and myocyte lineages have been demonstrated ${ }^{[6]}$. In addition to their easy availability as a human source and the absence of ethical restriction, this source has immense clinical importance in regenerative medicine.

Some previous studies have reported the effect of MSCs on cisplatin induced AKI. All of them used a small sample size. One used rat bone marrow MSCs ${ }^{[7]}$ and others used human ADMSCs ${ }^{[8,9]}$. The unique feature of our study was the use of large sample size, longterm follow up and assessment of oxidative stress markers levels for evaluating an early protective and late ameliorating effect of ADMSCs on cisplatin induced kidney injury.

\section{Materials and methods}

The Local Ethical Committee, Faculty of Medicine and Mansoura University, Egypt approved the experimental protocol. 


\section{ADMSC culture}

ADMSCs were isolated from human abdominal fat tissue collected during liposuction Surgery at Plastic Surgery Hospital, Faculty of Medicine, Mansoura University, Egypt. All eligible patients or their guardians provided their written informed consent and permission to isolate the MSCs from fat tissues. The culture methods were based on the method of Bunnell et $a l^{[10]}$. The tissue was washed with phosphate-buffered saline (PBS) containing 1\% antibioticantimycotic solution (Thermo scientific, USA) thrice, until all blood vessels and connective tissue appear liberated. This step was followed by digestion with trypsin (Sigma-Aldrich, USA) $0.125 \%$ at $37{ }^{\circ} \mathrm{C}$ with shaking at $100 \mathrm{rpm}$ ( $3 \mathrm{ml}$ for each $1 \mathrm{gm}$ Adipose tissue) for 60 min. The tissue digestion was checked every $15 \mathrm{~min}$ and the tissue digestion vessel was shaken vigorously. After digestion, trypsin activity was neutralized by adding equal volume of Dulbecco's modified Eagle's medium (DMEM; Lonza, Verviers, Belgium) containing $10 \%$ fetal bovine serum (FBS; Thermo scientific, USA), to the tissue sample. The cell suspension was filtered through $100 \mu \mathrm{m}$ filters (BD Falcon, USA) for avoiding the solid aggregates. The sample was then centrifuged at $2000 \mathrm{rpm}$ for $5 \mathrm{~min}$ at room temperature. The samples were taken out of the centrifuge and shaken vigorously to complete the separation of the stromal cells from the primary adipocytes. The centrifugation step was repeated and the supernatant was removed without disturbing the cells. The pellet was suspended in $1 \mathrm{ml}$ of lysis buffer (Promega, Germany) to lyse the RBCs and then incubated for $10 \mathrm{~min}$. Then the pellet was washed with $10 \mathrm{ml}$ of PBS+1\% antibiotic-anti mycotic and centrifuged at $2000 \mathrm{rpm}$ for $5 \mathrm{~min}$. Supernatant was removed and the cell pellet was suspended in DMEM with 20\% FBS and $1 \%$ antibiotic-anti mycotic solution in $25-\mathrm{cm}^{2}$ culture flask and maintained in an incubator supplied with humidified atmosphere of $5 \% \mathrm{CO}_{2}$ at $37^{\circ} \mathrm{C}$.

\section{Cell culture}

After a day, non-adherent cells were removed by two to three washes with PBS and adherent cells were further cultured in complete medium. The medium was changed every 3 days until the monolayer of adherent cells reached $70-80 \%$ confluence. Then, we used trypsinization for cell splitting by employing trypsin-EDTA solution (0. $25 \%$, sigma Aldrich, USA) for passage 1 . The number of cells was evaluated using hemocytometer and cellular viability was assessed by the Trypan Blue exclusion test. Each $250-300 \times 10^{3}$ cells were inoculated in a $75 \mathrm{~cm}^{2}$ culture flask that was incubated at $37^{\circ} \mathrm{C}$ and $5 \% \mathrm{CO}_{2}$. Cell cultivation was maintained up to the third passage.

\section{Phenotypic analysis with Flow cytometry}

Cells were characterized using cell surface mesenchymal markers by fluorescence-activated cell sorting (FACS) analyses. The cells were stained with different fluorescent labeled monoclonal antibodies (mAbs), CD29 and CD90 (eBioscience), CD 13, CD 105, CD34 and $14 \mathrm{mAbs}$ as hematopoietic lineages markers. In brief, $5 \times 10^{5}$ cells (in $100 \mu \mathrm{l} \mathrm{PBS} / 0.5 \% \mathrm{BSA} / 2 \mathrm{mmol} / \mathrm{L}$ EDTA) were mixed with $10 \mu \mathrm{l}$ of the fluorescent labeled $\mathrm{mAb}$ and incubated in the dark at $2-8{ }^{\circ} \mathrm{C}$ for $30 \mathrm{~min}$. They were then washed twice with PBS containing $2 \%$ BSA. The pellet was re-suspended in PBS and analyzed immediately using flow cytometry. The fluorescence intensity of the cells was evaluated by EPICS-XL flow cytometry (Coulter, Miami, FL, USA).

\section{Colony forming unit-fibroblast (CFU-F)}

Fibroblast colony growth was evaluated in the primary cells grown on tissue culture in six-well dishes ${ }^{[11]}$. About 100 cells were plated in $100-\mathrm{mm}$ tissue culture dish (Falcon) in complete culture medium. Cells were incubated for $10-14$ days at $37^{\circ} \mathrm{C}$ in $5 \%$ humidified $\mathrm{CO}_{2}$, washed with PBS and fixed in $95 \%$ ethanol for 5 minutes, then incubated for 20 - 30 minutes at room temperature in $0.5 \%$ crystal violet (sigma Aldrich, USA) in 95\% ethanol and then the plates were washed twice with distilled $\mathrm{H}_{2} \mathrm{O}$. The plates were dried and the CFU-F units counted.

\section{Differentiation capability of hADMSCs}

\section{a) Osteogenic Differentiation:}

Passage 3 MSCs were harvested by trypsin digestion as described above. The cells were counted and seeded at a density of $5 \times 10^{4}$ per well in a 6-well plate. Then at $80 \%$ confluence, to four of the wells, osteogenesis differentiation media: DMEM supplemented with $10 \%$ FBS, $0.1 \mu \mathrm{M}$ dexamethasone, $50 \mu \mathrm{M}$ Ascorbic acid, $10 \mathrm{mM} \beta$-glycerol phosphate (Sigma-Aldrich, USA) was added. To the other two wells, complete culture media as negative control ${ }^{[12]}$ was added. The media were changed twice per week for 2-3 weeks. The differentiation potential for osteogenesis was assessed by $40 \mathrm{mM}$ Alizarin $\mathrm{Red}(\mathrm{pH}$ 4.1 ) after fixation in $10 \%$ neutral buffered formalin ${ }^{[13]}$.

\section{b) Adipogenic Differentiation:}

Passage 3 MSCs harvested by trypsin digestion as described above were counted and seeded at a density of $10 \times 10^{4}$ per well in a 6-well plate, then at $100 \%$ confluence. To four of the wells, adipogenesis differentiation media: DMEM supplemented with $10 \% \mathrm{FBS}, 1 \mu \mathrm{M}$ dexamethasone, 500- $\mu \mathrm{M}$ isobutylmethylxanthine (IBMX) $5 \mu \mathrm{g} / \mathrm{ml}$ insulin, $200 \mu \mathrm{M}$ Indomethacin (Sigma-Aldrich, USA) was added. To the other two wells, complete culture media as negative control was added. The media were changed twice per week for 2 weeks ${ }^{[12]}$. The differentiation potential for adipogenesis and formation of intracellular lipid droplets were assessed by Oil-red-O after fixation in $10 \%$ neutral buffered formalin ${ }^{[13]}$.

\section{c) Chondrogenesis Differentiation:}

MSCs were harvested and $6 \times 10^{5}$ cells were centrifuged to form a pellet on the bottom of a 15-ml polypropylene tube (Falcon). The micro mass was cultured in $500 \mu 1$ of chondrogenic medium that consisted of $50 \mu \mathrm{g} / \mathrm{ml}$ ascorbic acid 2-phosphate and $1 \mathrm{ng} / \mathrm{ml}$ TGF$\beta 1^{[12]}$ (Sigma). After 3 weeks of culture, cell clumps were harvested, embedded in paraffin, cut into $3-\mu \mathrm{m}$ sections and stained for glycosaminoglycans using $0.1 \%$ safranin O (Sigma).

\section{Detection by Image J analysis}

Twenty different digital images corresponding to four different preparations of osteogenic, adipogenic, chondrogenic differentiated cells and undifferentiated controls were analyzed using Image J 1.42 software on an appropriate threshold. Image $\mathbf{J}$ can calculate area and pixel value statistics of user-defined selections and intensity threshold objects. It can measure distances and angles. It can create density histograms and line profile plots ${ }^{[14]}$.

\section{Identification of MSCs differentiation to adipocytes by RT-PCR analysis}

MSCs differentiation to adipocytes was further demonstrated by Real-time quantitative reverse transcriptase-polymerase chain reaction (RT-PCR) analysis of adipocytic and osteocytic markers expression (Table 1). Total RNA was isolated from MSCs and realtime reverse transcriptase-PCR was performed as described previously ${ }^{[12]}$. Selective markers and primer sequences were used. Glyceraldehyde-3-phosphate dehydrogenase (GAPDH) was used as an internal standard. 
Table 1: Primers for Adipogenic and osteogenic differentiation RT-PCR of human adipose derived mesenchymal stem cells

\begin{tabular}{|c|c|c|c|}
\hline \multirow{5}{*}{ 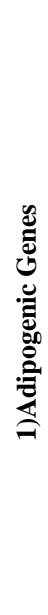 } & & Forward Primer & Reverse Primer \\
\hline & Adiponectin & TCCTGCCAGTAACAGGGAAG & GGTTGGCGATTACCCGTTTG \\
\hline & $\begin{array}{c}\text { adipocyte lipid-binding } \\
\text { protein (ALBP) }\end{array}$ & TACCTGGAAACTTGTCTCCAGTGAA & CCATTTCTGCACATGTACCAGGACA \\
\hline & Lipoprotein Lipase & CTGCTGGCGTAGCAGGAAGT & GCTGGAAAGTGCCTCCATTG \\
\hline & Lipten & TGACACCAAAACCCTCATCA & TCATTGGCTATCTGCAGCAC \\
\hline 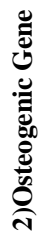 & Osteocalcin & ACACTCCTCGCCCTATTG & GATGTGGTCAGCCAACTC \\
\hline
\end{tabular}

Total RNA extracted from the cultured cells, following the manufacturer's instructions. For adipogenic differentiation, the cells assessed using specific Primers identified in Table 1. The RT-PCR procedure performed using the One Step RT-PCR kit, beginning at $50^{\circ} \mathrm{C}$ for $30 \mathrm{~min}$ and $95^{\circ} \mathrm{C}$ for $15 \mathrm{~min}$ for reverse transcription and then followed by 35 cycles. Each cycle consisted of denaturation at $94^{\circ} \mathrm{C}$ for $1 \mathrm{~min}$, annealing at $57^{\circ} \mathrm{C}$ for $1 \mathrm{~min}$, elongation at $72^{\circ} \mathrm{C}$ for 1 min and the final extension at $72^{\circ} \mathrm{C}$ for $10 \mathrm{~min}$. The amplified DNA fragments visualized through $2 \%$ agarose gel electrophoreses then photographed under UV light.

hADMSCs in basic culture conditions expressed adiponectin and adipocyte lipid-binding protein (ALBP).

\section{Animal Treatment}

Male Sprague-Dawley rats (250-300 g) were maintained in a 12:12-h light-/dark cycle in a temperature and humidity- controlled facility. Standard rat chow and water provided. Animal studies were conducted according to the experimental protocol that was approved by the Local Ethical Committee, Faculty of Medicine, Mansoura University. Animals were divided into four equal groups (each group=20). The negative control group received a single injection of saline intraperitoneally. The positive control cisplatin group was given a single intraperitoneal injection of cisplatin (10 mg/kg body wt.) and an equal volume of PBS instead of ADMSCs. The ADMSCs group was given a single injection of ADMSCs $\left(5 \times 10^{6}\right.$ cells $)$ by tail vein. The cisplatin and ADMSCs group received single dose cisplatin and only one dose ADMSCs given at day 1 after cisplatin injection. For long term study on the protective effect of ADMSC against cisplatin AKI, each main group was further divided according to the timing of sacrifice, into four equal subgroups (each subgroup $n=5$ ). Subgroup A sacrificed after
4 days; subgroup B sacrificed after 7 days; subgroup C sacrificed after 11 days and subgroup D sacrificed after 30 days. Before sacrifice, 24 hrs.-urine was collected using a metabolic cage. Rats were sacrificed using an over dose of thiopental. Blood samples were collected from the heart immediately centrifuged at approximately $3000 \mathrm{~g}$ for $5 \mathrm{~min}$., and then taken for biochemical measurements. The kidneys were removed for histological evaluation.

\section{Assessment of renal function}

Serum samples were examined for blood urea nitrogen (BUN), serum creatinine, creatinine clearance using Diamond Diagnostics (Egypt) standard diagnostic kits.

\section{Assessment of Oxidative stress markers}

Kidney tissue homogenate was used for assessment of MDA, SOD, and GSH, using Biodiagnostic Co. (Egypt) for all the groups and subgroups.

\section{Renal histology and damage scoring}

The left kidney was perfused in a retrograde fashion through the abdominal aorta using saline $0.9 \%$ until complete clearance of the perfusion fluid and then $10 \%$ neutral buffered formalin for in situ fixation. Renal samples were coded and processed for light microscopic examination. Histopathological changes were analyzed in the different regions of the kidney (cortex, outer strip of outer medulla "OSOM", inner strip of outer medulla "ISOM" and inner medulla using H\&E, periodic acid- Schiff (PAS) reagent and Masson trichrome stains according to a new scoring system (submitted for publication). 


\section{Active injury changes}

These include necrotic tubules and interstitial infiltration by inflammatory cells. Necrotic tubules were scored according to the number of necrotic tubules counted/high power field (HPF) and scored to $1,2,3$ and 4 corresponding to $1-3,4-5,6-10$ and $>10$ necrotic tubules / HPF. The inflammatory cells were scored as 1, 2, 3 corresponding to mild, moderate \& severe. The maximum score of active injury is 7 .

\section{Regenerative changes}

These include presence of mitosis, solid cellular sheets between the tubules, intraluminal cellular proliferation forming solid tubules, tubules lined with large vesicular nuclei and tubules lined by cells having hyperchromatic prominent nuclei and little cytoplasm giving the luminal border a festooned appearance. Each of the solid cellular sheets and solid tubules was counted as 1-2, 3-5 and > 5/ HPF were scored as 1, 2 and 3 respectively. Mitosis was scored as 1,2 and 3 corresponding to $1-2,3-5$ and $>5 / 10 \mathrm{HPF}$. Tubules with large vesicular nuclei and tubules with basophilic prominent nuclei got score 1 , when present and got score 0 , if absent. The maximum score of regeneration was 11 .

\section{Chronic changes}

These include atrophic tubules with flat lining, casts, and thick basement membrane and interstitial fibrosis. The maximum chronicity score was 7; where the number of atrophic tubules /HPF of 1-5, 6-10 and $>10$ were scored 1,2 and 3 respectively. In addition, the percentages of interstitial fibrosis / HPF of 25, 25-50, 50-75 and more than $75 \%$ got scores of $1,2,3$ and 4 respectively.

\section{Statistical analysis}

Data was analyzed using SPSS version 16. Variables were tested for normality of distribution using Kolmogrov-Smirnov test. Both the biochemical and the morphological results were non-parametric. Kruskal-Wallis test was used for comparison. The results are presented as mean \pm SD. $\mathrm{P} \leq 0.05$ was considered statistically significant.

\section{Results}

\section{Isolation and characterization of human ADMSCs}

Human ADMSCs were isolated from human fat tissue that was obtained from abdominal fat of liposuction surgery. Attachment of spindle-shaped cells to tissue culture plastic flask was observed after 1 day of culture of the ADMSCs. After 5 days, spindle-shaped cells reached $80 \%$ confluency. Morphology of cells changed gradually with the increase in passage number. Cells became more flat-shaped with increase in passage number (Figure 1A).

\section{Colony forming unit- fibroblast (CFU-F)}

CFU-F assay was a suitable tool for evaluating the proliferation and colonogenic capacity of the cells (3rd passage) expanded in culture. The colony number of 100 ADMSCs per 100-mm tissue culture dish was $38 \pm 1$ (Figure $1 \mathrm{~B} \& \mathrm{C}$ ). The ADMSCs isolated from human adipose tissue used in our experiments, were plastic-adherent and capable of extensive proliferation when maintained in their standard culture conditions.
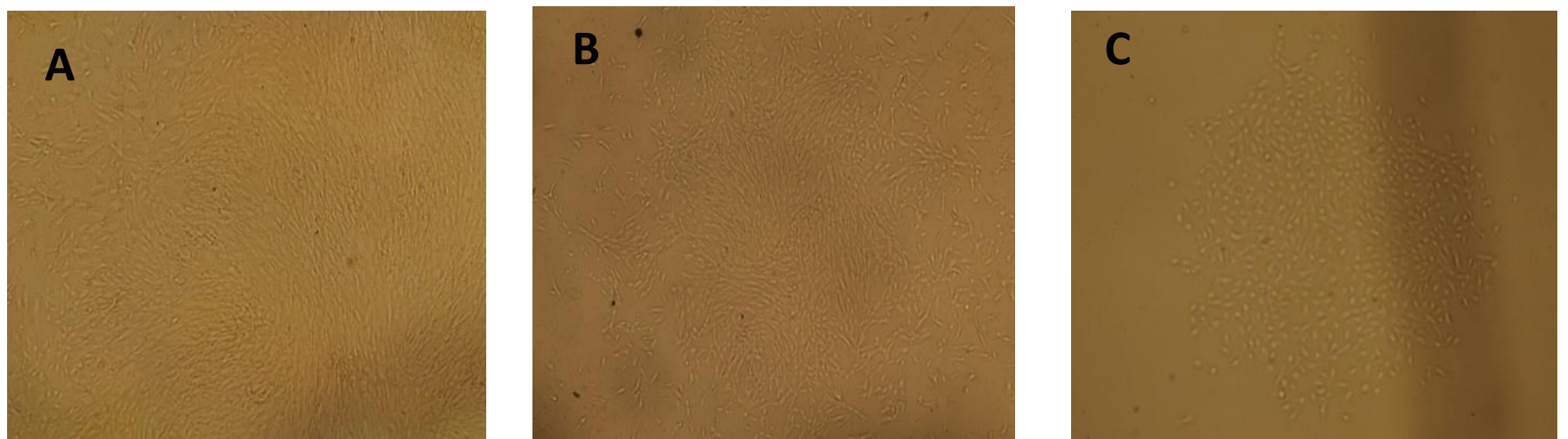

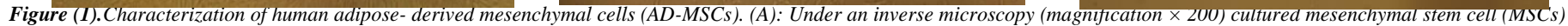

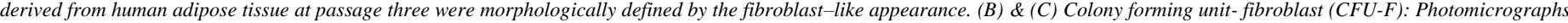

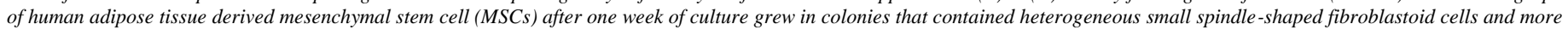
rounded cells $\{A$ and B original magnification $\times 100\}$
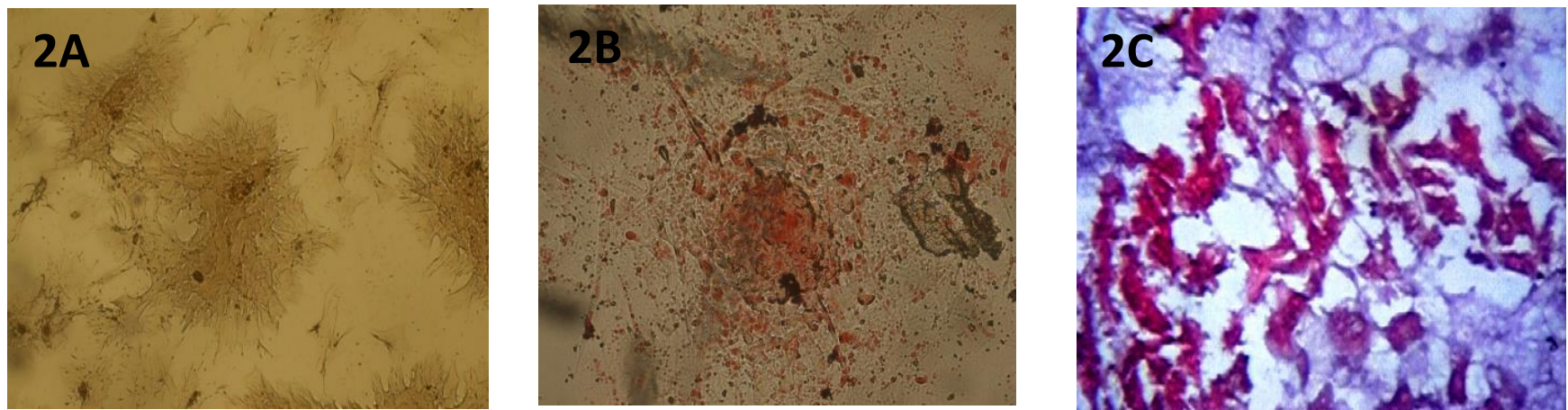

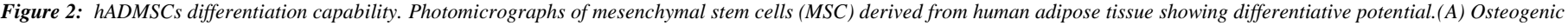

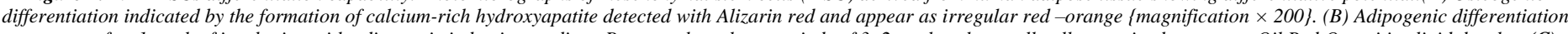

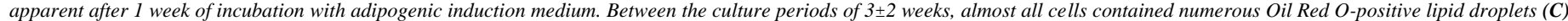

Chondrogenic differentiation apparent after 1 week of incubation with chondrogenic induction medium. Between the culture periods of $3 \pm 2$ weeks, almost all cells contained numerous glycosaminoglycans. 


\section{Differentiation capability of hADMSCs}

Distinct culture conditions demonstrated the pluripotency of ADMSCs. They enabled cells to differentiate into osteoblasts, adipoblasts and chondroblasts. According to Image $\mathbf{J}$ analysis and spectrophotometric analysis, Image $\mathrm{J}$ analysis of differentiated vs. undifferentiated cells resulted in fold increase of ADMSCs for each type of cells; $3.4 \pm 0.5$ for osteoblasts, $2.6 \pm 0.7$ for adipoblasts and $3.3 \pm 0.6$ for chondroblasts (Figure $2 \mathrm{~A}, \mathrm{~B} \& \mathrm{C}$ respectively).
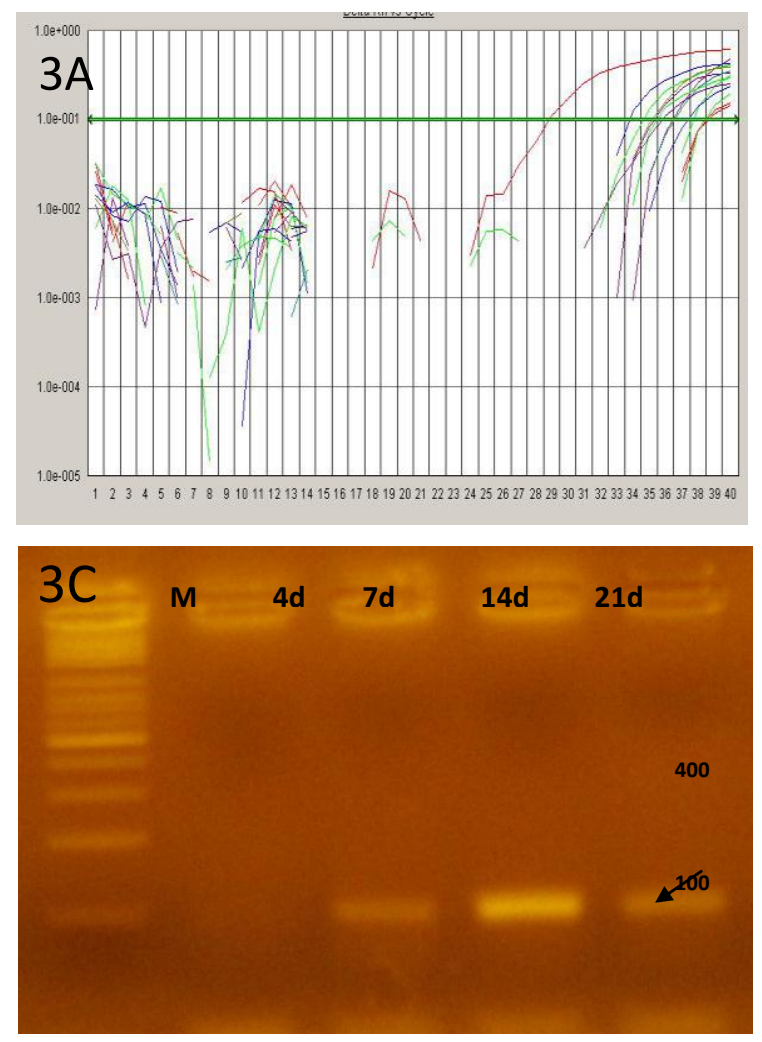

\section{Immunophenotypic characterization ( $R T$ - PCR)}

In Adipogenic culture conditions a transcription factor was identified (Figure 3). Figure 3A shows amplification plot of leptin expression at 4,7,14 days. ADMSCs expressed lipoprotein lipase (Figure 3B), leptin (Figure 3C) and adiponectin (Figure 3D) as demonstrated by Gel electrophoresis. For osteocytic gene markers expression, under human adipose osteogenesis culture conditions ADMSCs expressed osteocalcin at different time intervals of 4, 7, 14 and 21 days (Figure 4).
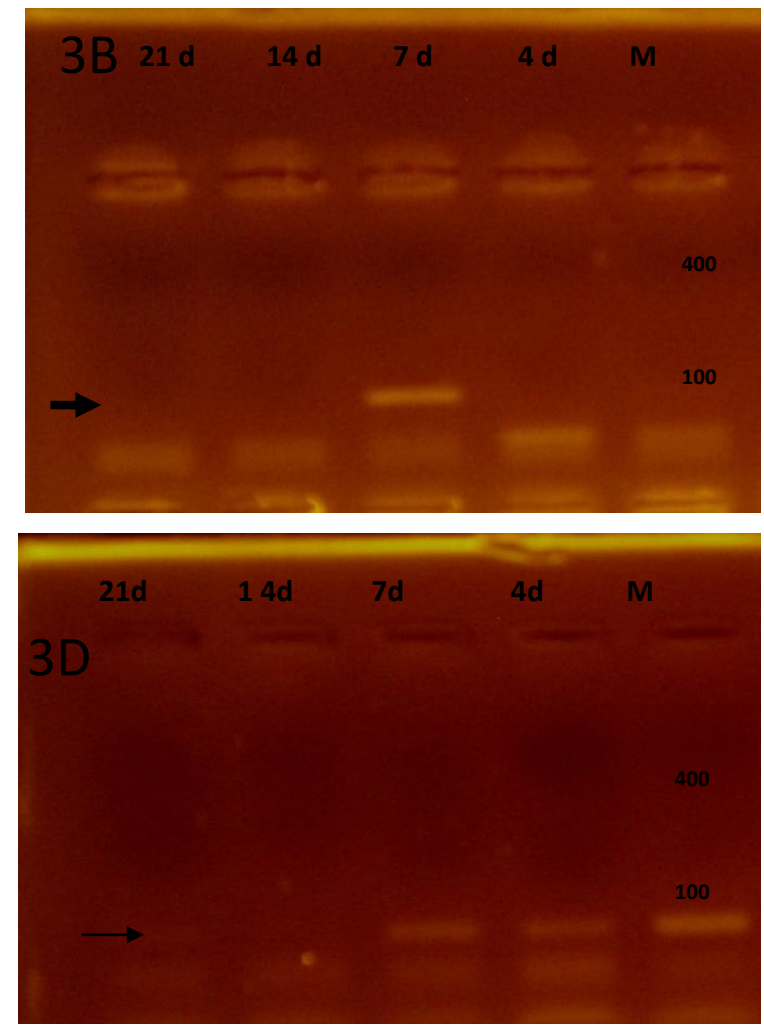

Figure 3: ADMSCs differentiation demonstrated adipogenic differentiation by RT-PCR analysis of genes markers expression; (A) Amplification Plot of adipocytic marker gene (Leptin) at 4, 7, 14, 21 days. (B) Agarose gel electrophoresis showing positive expression of lipoprotein lipase at day 7 by RT-PCR. (C) Agarose gel electrophoresis showing positive expression of leptin at day 7, 14, 21 by RT-PCR. (D) Agarose gel electrophoresis showing positive expression of adiponectin

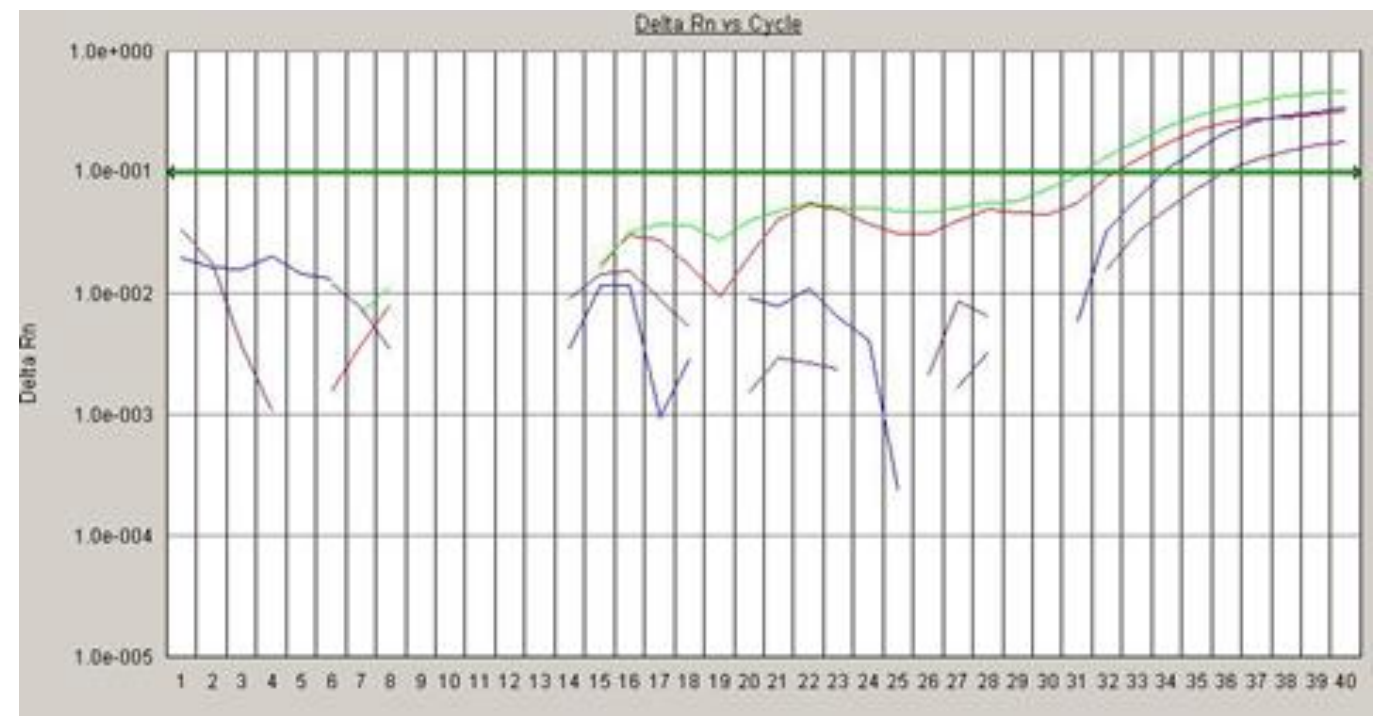

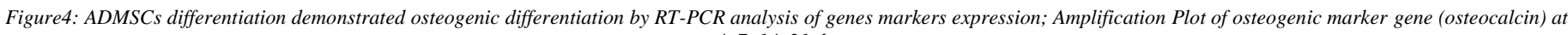
4, 7, 14, 21 days. 
Phenotypic analysis

We carried on further characterization of ADMSCs. Fluorescenceactivated cells confirmed the endogenous expression of the most important surface markers for MSCs; CD90, CD29, CD105 and CD13. On the other hand, those rarely expressed CD34 and CD14 showed negative results (Figure 5).

\section{ADMSCs' protective effect against renal impairment caused by cisplatin}

Evaluated by serum creatinine, BUN and creatinine clearance (Table 2). I.P injection of $5 \mathrm{mg} / \mathrm{kg}$ cisplatin induced significant increases in serum creatinine and BUN, which peaked at days 4 and 7 and declined at days 11 .

They stabilized at the $30^{\text {th }}$ day to values slightly higher than baseline. Meanwhile, intravenous injection of $5 \times 10^{5}$ MSC on day 1 after receiving cisplatin strongly protected renal function at days $4,7,11$ and 30 as reflected by significantly lower serum creatinine and BUN values in comparison to cisplatin-treated rats that were given fresh culture media intravenously. Figure 6A indicates the long-term protective effect of ADMSCs on kidney function in term of creatinine clearance.
ADMSCs effect on oxidative stress caused by cisplatin: (Table2).

Cisplatin increased renal tissue MDA detectable at days 4, 7, 11 and 30. Intravenous injection of $5 \times 10^{6} \mathrm{MSC}$ into the rats on day 1 after receiving cisplatin induced significant decrease in MDA measured at days 4, 7, 11 and 30 when compared with cisplatin-injected rats treated with fresh culture media via tail vein. ADMSCs increased significantly, the renal tissue homogenate GSH and SOD levels content which was demonstrated in MSCs group at all intervals when compared to the non-treated groups. Figure $6 \mathrm{~B}$ indicates the protective effect of ADMSCs on kidney function in the term of MDA on the long term.

ADMSCs reduced renal injury caused by cisplatin on long-term study

Evaluated by $\mathrm{H} \& \mathrm{E}$ that was performed on the kidney sections. Regenerative changes were found as early as the 4th day in addition to less tubular necrosis and atrophy than in cisplatin injected rats (Group I) and cisplatin injected rats treated with culture media through tail vein (Group III). Moreover, the ADMSCs continued to offer protection to renal tissue and ameliorate renal injury until the 30th day.

The detailed histological changes were observed in kidney tissue samples at the different time intervals (Figure 7 A \& B) (Table 3):

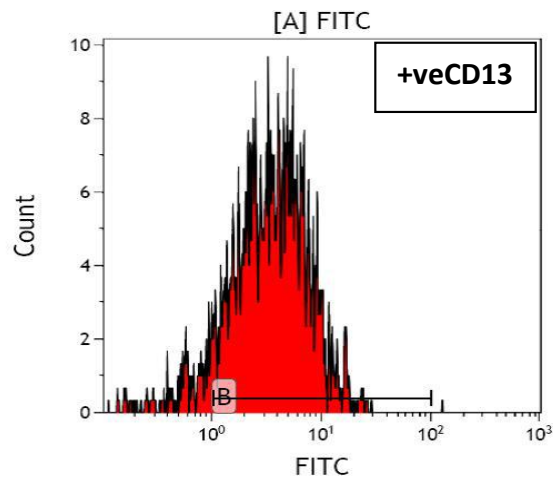

Gate Number \%Gated

All $\quad 1,544 \quad 100.00$

B $\quad 1,369 \quad 88.67$

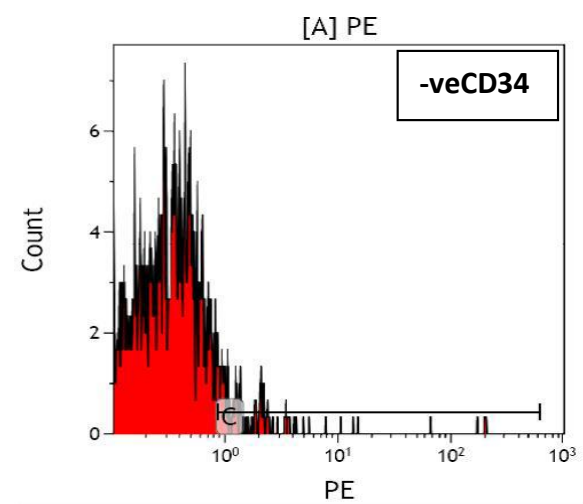

Gate Number \%Gated

All $\quad 1,460 \quad 100.00$

C $\quad 85 \quad 5.82$

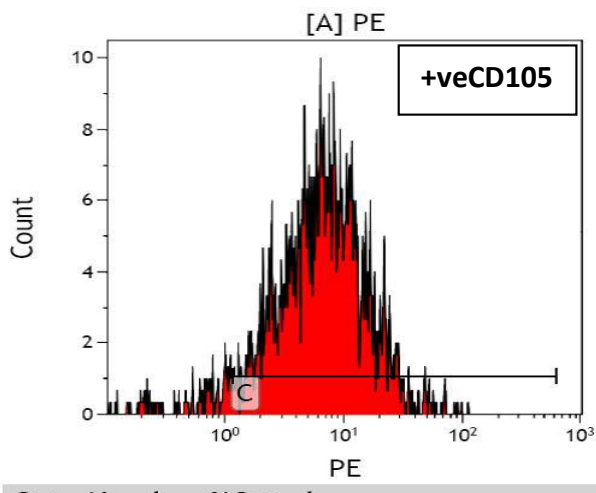

Gate Number \%Gated

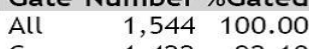

C $\quad 1,422 \quad 92.10$

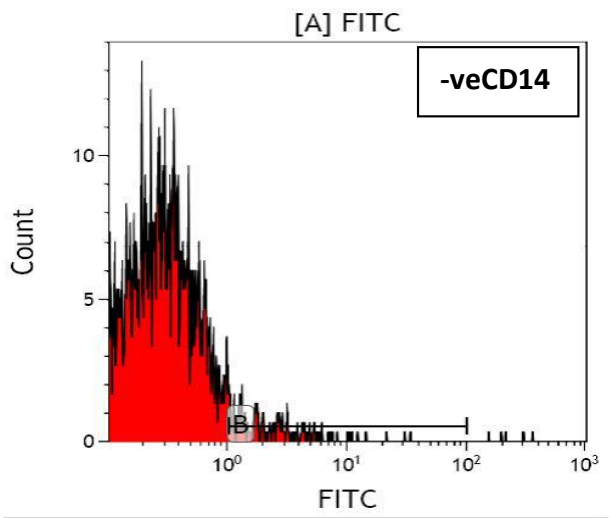

Gate Number \%Gated

$\begin{array}{lrr}\text { All } & 2,733 & 100.00 \\ \text { B } & 115 & 4.21\end{array}$

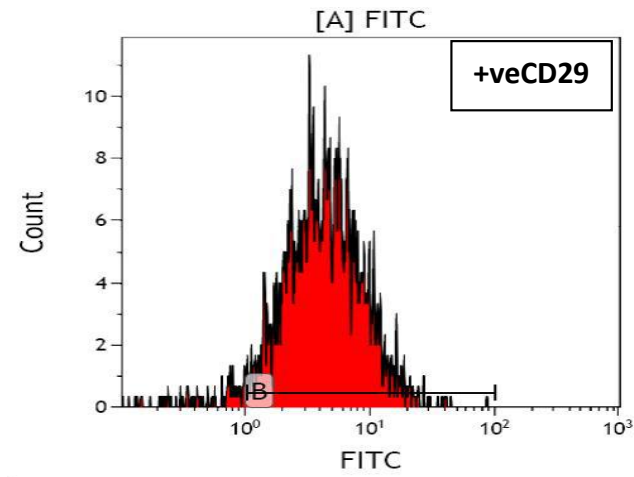

Gate Number \%Gated

All $1,460 \quad 100.00$

B $\quad 1,376 \quad 94.25$

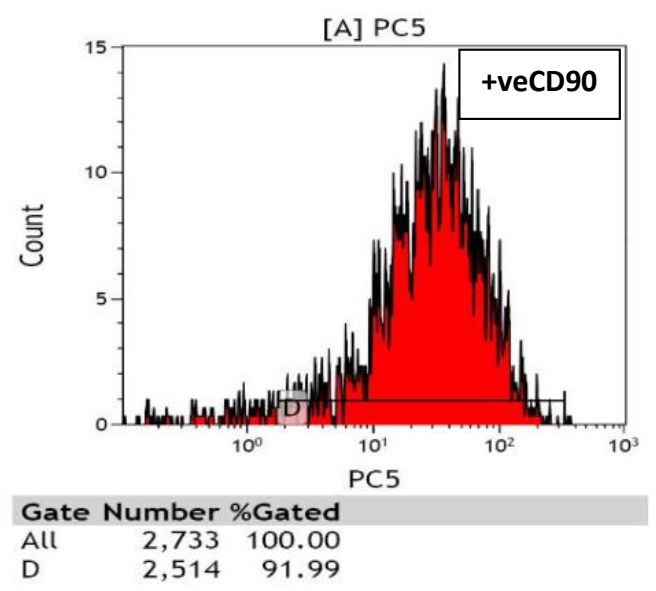

Figure 5: Flow cytometry analysis of surface markers on cultured human adipose tissue mesenchymal stem cells revealed that their expression of surface antigens such as CD29 (94\%), CD 90 (92\%), CD 105 (92\%) and CD13 (89\%). (Passage 4:8) was strongly positive; but CD14 (4\%) and CD34 (6\%) was negative. 
Table 2: ADMSCs' effects on renal function and tissue oxidative stress markers level in cisplatin- induced nephrotoxicity on long term. (mean \pm SD)

\begin{tabular}{|c|c|c|c|c|}
\hline & Contr & Cisplatin & Cisplatin+C.Medium & Cisplatin+ SCs \\
\hline \multicolumn{5}{|c|}{ S. Creatinine(mg/dl) } \\
\hline Day 4 & $0.47 \pm 0.11$ & $1.92 \pm 0.04 *$ & $1.89 \pm 0.12^{*}$ & $1.02 \pm 0.11 *^{\circ}$ \\
\hline Day 7 & $0.48 \pm 0.13$ & $1.61 \pm 0.06^{* \hbar}$ & $1.62 \pm 0.04 * \hbar$ & $0.85 \pm 0.11 *$ \\
\hline Day 11 & $0.48 \pm 0.18$ & $0.97 \pm 0.14 *$ *t† & $0.98 \pm 0.18^{*}+\hbar$ & $0.70 \pm 0.08^{* \dagger}$ \\
\hline Day 30 & $0.43 \pm 0.11$ & $0.76 \pm 0.04^{* t \dagger}$ & $0.79 \pm 0.05^{*} \star^{\dagger}$ & $0.56 \pm 0.07 * \frac{1}{* \dagger}$ \\
\hline \multicolumn{5}{|c|}{ Cr.Clearance(ml/min./100gm) } \\
\hline Day 4 & $1.600 \pm 0.860$ & $0.007 \pm 0.002 *$ & $0.008 \pm 0.002^{*}$ & $0.017 \pm 0.009^{*}$ \\
\hline Day 7 & $1.600 \pm 0.760$ & $0.014 \pm 0.001 * \hbar$ & $0.012 \pm 0.003^{*}$ & $0.045 \pm 0.012 * \$$ \\
\hline Day 11 & $1.600 \pm 0.790$ & $0.054 \pm 0.016^{* t \dagger}$ & $0.056 \pm 0.020^{* * \dagger}$ & $0.650 \pm 0.117 *^{\circ}+\dagger$ \\
\hline Day 30 & $1.600 \pm 0.350$ & $0.340 \pm 0.240 *$ *t॰ & $0.360 \pm 0.320^{*} * \frac{1}{\bullet}$ & $0.860 \pm 0.243 *^{\circ}+\dagger$ \\
\hline \multicolumn{5}{|c|}{ S.BUN(mg/dl) } \\
\hline Day 4 & $054.36 \pm 03.31$ & $266.70 \pm 08.70 *$ & $265.30 \pm 08.60 *$ & $097.80 \pm 07.67 *^{\circ}$ \\
\hline Day 7 & $053.39 \pm 04.51$ & $228.70 \pm 18.00^{* \hbar}$ & $236.00 \pm 15.00^{* \hbar}$ & $076.40 \pm 04.30^{* *^{\circ}}$ \\
\hline Day 11 & $054.43 \pm 03.91$ & $137.40 \pm 14.70^{*{ }^{\dagger}}$ & $138.60 \pm 16.30 * \hbar \dagger$ & $068.34 \pm 04.60^{* \circ \dagger}$ \\
\hline Day 30 & $054.55 \pm 03.62$ & $111.46 \pm 11.50^{* * \dagger \bullet}$ & $112.58 \pm 08.40^{*+\bullet}$ & $068.34 \pm 04.60^{*}+\pitchfork$ \\
\hline \multicolumn{5}{|c|}{ MDA tissue (nmol/gm) } \\
\hline Day 4 & $14.50 \pm 3.43$ & $67.40 \pm 3.40^{*}$ & $69.50 \pm 4.80^{*}$ & $34.20 \pm 8.54^{\circ}$ \\
\hline Day 7 & $14.50 \pm 3.89$ & $65.10 \pm 4.54 *$ & $63.20 \pm 3.87 *$ & $25.40 \pm 2.86^{* \circ+}$ \\
\hline Day 11 & $14.60 \pm 2.56$ & $34.10 \pm 4.70^{*{ }^{\dagger}}$ & $37.20 \pm 4.60 *{ }^{* \dagger \dagger}$ & $17.30 \pm 3.82^{\circ \dagger}$ \\
\hline Day 30 & $14.50 \pm 2.46$ & $32.80 \pm 5.10^{* \dagger \dagger}$ & $33.20 \pm 5.40 *$ *t & $16.32 \pm 3.65^{\circ \dagger}$ \\
\hline \multicolumn{5}{|c|}{ Tissue GSH (mmol/gm) } \\
\hline Day 4 & $5.36 \pm 0.17$ & $0.26 \pm 0.03^{*}$ & $0.27 \pm 0.05^{*}$ & $0.77 \pm 0.03 *^{\circ}$ \\
\hline Day 7 & $5.38 \pm 1.15$ & $0.53 \pm 0.04 * \hbar$ & $0.56 \pm 0.05^{* \hbar}$ & $2.56 \pm 0.05 *$ \\
\hline Day 11 & $5.35 \pm 0.18$ & $1.38 \pm 0.42 *$ *t† & $1.35 \pm 0.35^{* \dagger \dagger}$ & $3.53 \pm 0.21 *$ \\
\hline Day 30 & $5.39 \pm 0.35$ & $1.92 \pm 0.04 *$ & $1.95 \pm 0.08^{*}+t^{\bullet}$ & $4.12 \pm 0.22 *^{\circ}+\bullet$ \\
\hline \multicolumn{5}{|c|}{ Tissue SOD U/gm) } \\
\hline Day 4 & $20.86 \pm 1.24$ & $3.25 \pm 0.64 *$ & $3.70 \pm 0.65^{*}$ & $6.85 \pm 0.52 *^{\circ}$ \\
\hline Day 7 & $20.82 \pm 1.64$ & $6.24 \pm 0.57 * \sharp$ & $6.46 \pm 0.62 * \ddagger$ & $10.67 \pm 0.38 *^{\circ}$ \\
\hline Day 11 & $20.78 \pm 1.28$ & $9.96 \pm 0.30^{* * \hbar t}$ & $9.94 \pm 0.52 * \dagger$ & $15.62 \pm 0.43^{\circ}+\phi$ \\
\hline Day 30 & $20.73 \pm 0.84$ & $15.24 \pm 0.46^{*+\bullet}$ & $15.43 \pm 0.52 * 末 \bullet$ & $18.67 \pm 0.42^{\circ}$ \\
\hline
\end{tabular}

Significant difference compared to corresponding * control, ${ }^{\circ}$ cisplatin groups

Significant difference compared to intra-group day $4^{\ddagger}$, day $7^{\dagger}$, day $11^{\bullet}$ by Kruskal-Wallis test at $\mathrm{P} \leq 0.05$ 


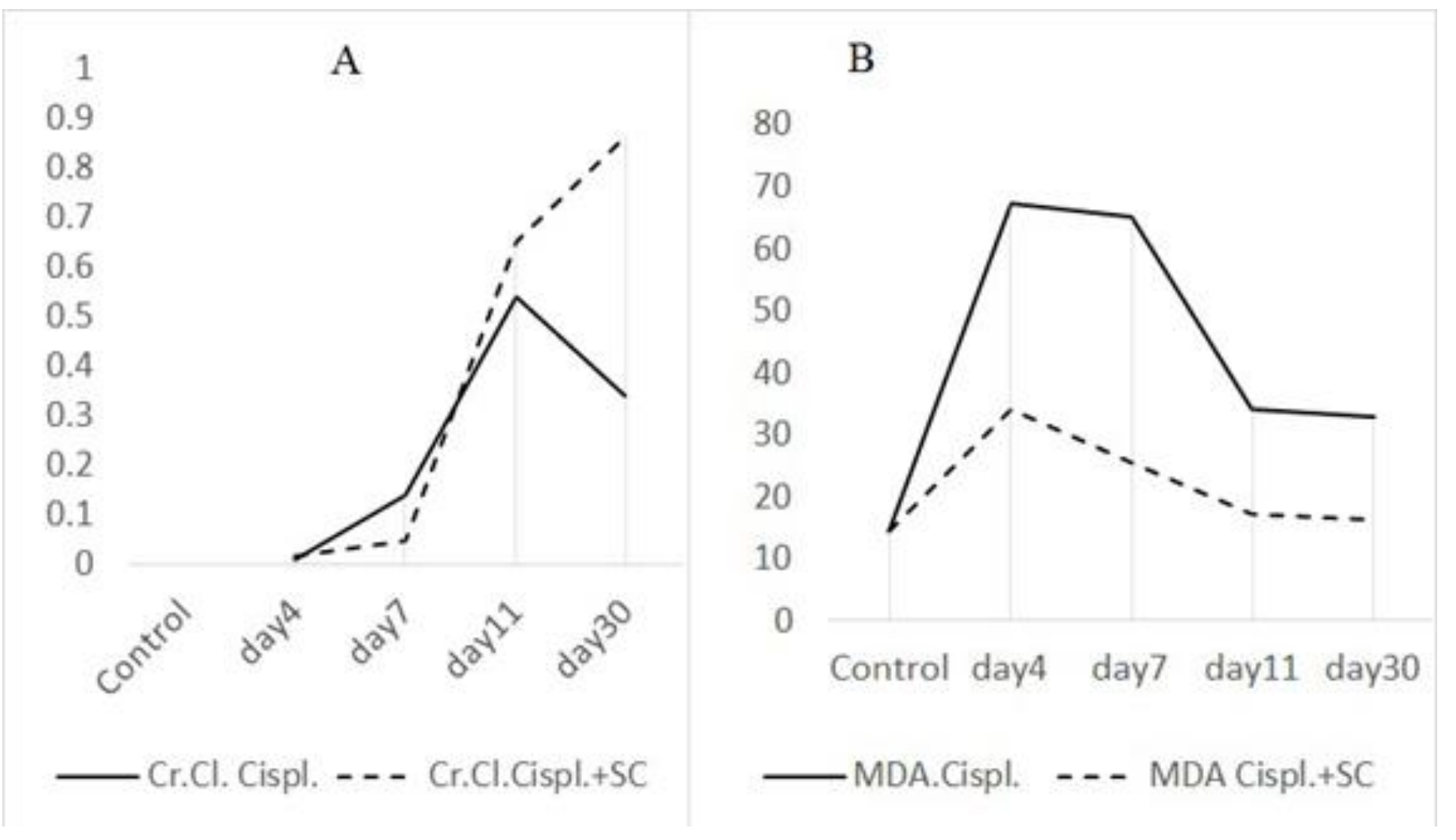

Figure 6: ADMSCs effect on A] creatinine clearance and on B] renal tissue MAD level in cisplatin induced AKI at different time intervals.
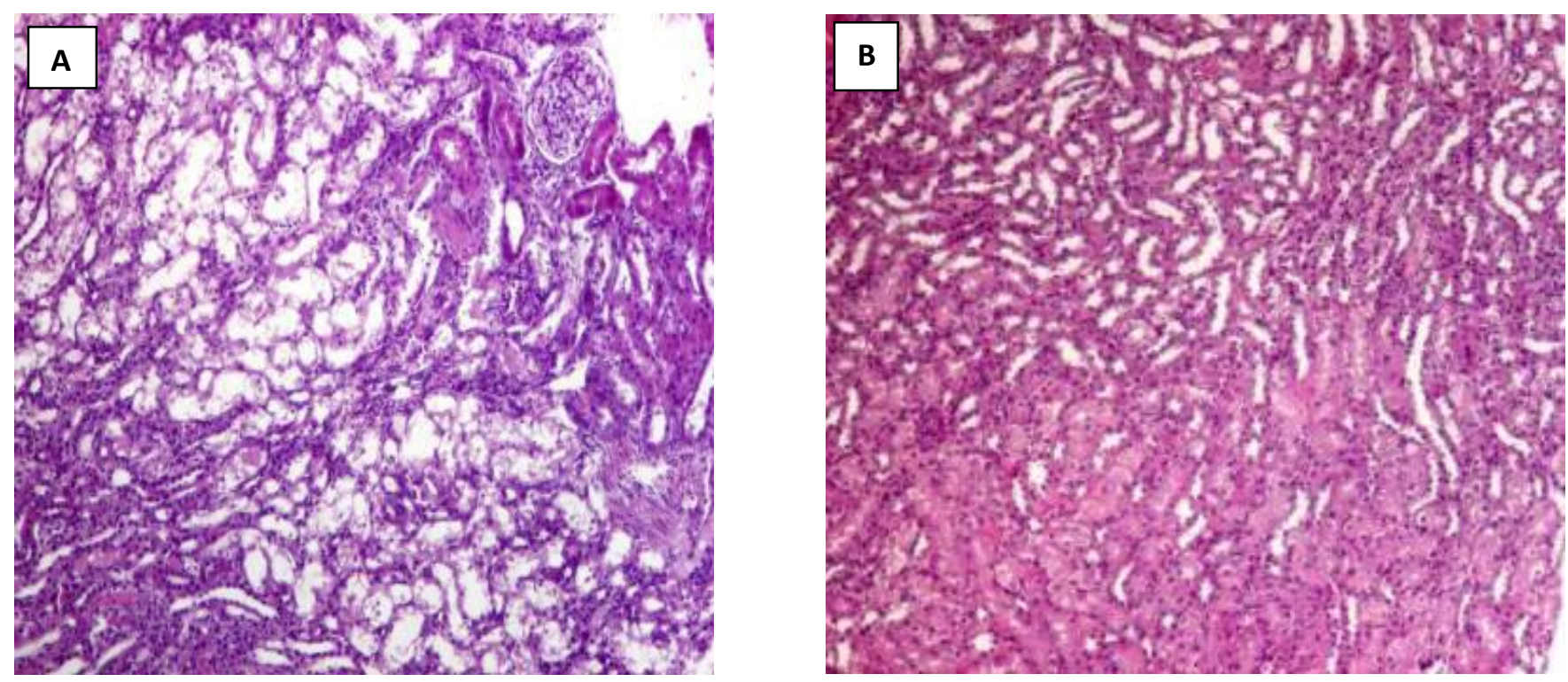

Figure 7: Long-term ADMSCS effects on Renal Histopathology and Scoring in cisplatin- induced nephrotoxicity (mean \pm SD).: Day 4 A) Sections taken from cisplatin injected rats (group I) after 4 days revealed marked necrotic and degenerative changes in the OSOM where the tubules are dilated with thin denuded lining epithelium. Degenerative changes with

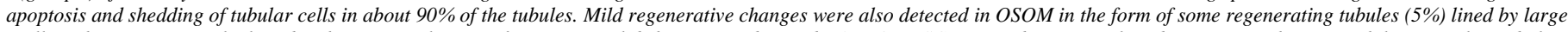
cells with prominent nucleoli and with occasional mitotic figures. No solid sheets were detected.B) In ADMSCs injected group VI, less degenerative changes with less complete tubular necrosis. Regenerative changes were markedly detected in the OSOM in the form of many regenerating tubules (70-80\%) lined by large cells with large hyperchromatic active nuclei with few solid sheets (less than 1/20 HPF). (HX\&E× 100\}. 
Renal anti-injury activity of ADMSCs in cisplatin induced nephrotoxicity

Table 3: ADMSCs effect on acute renal injury, regenerative and chronicity scores in the outer stripe of the outer medulla of rat kidney after cisplatin $(n=5$ in each group for each time subgroup; mean $\pm S D)$

\begin{tabular}{|c|c|c|c|c|}
\hline & Control & Cispl. & Cispl.+ C.Medium & Cispl.+ ADMSC \\
\hline \multicolumn{5}{|c|}{ Necrotic tub. } \\
\hline 4 & $0.0 \pm 0.0$ & $12.6 \pm 2.1^{*}$ & $8.4 \pm 1.7^{*}$ & $3.9 \pm 0.3^{\circ}$ \\
\hline 7 & $0.0 \pm 0.0$ & $8.6 \pm 1.3^{* t}$ & $8.3 \pm 1.5^{*}$ & $4.6 \pm 0.4^{*}$ \\
\hline 11 & $0.0 \pm 0.0$ & $7.4 \pm 1.8^{*}$ & $7.5 \pm 2.2^{*}$ & $2.6 \pm 0.2 *+\dagger$ \\
\hline 30 & $0.0 \pm 0.0$ & $4.7 \pm 0.1^{*}+t^{\circ}$ & $2.4 \pm 0.3$ * & $1.0 \pm 0.6^{*}+\bullet$ \\
\hline \multicolumn{5}{|c|}{ Inflam. cells } \\
\hline 4 & $0.0 \pm 0.0$ & $8.8 \pm 1.3^{*}$ & $8.4 \pm 1.6^{*}$ & $1.8 \pm 0.2^{*}$ \\
\hline 7 & $0.0 \pm 0.0)$ & $8.4 \pm 1.6^{*}$ & $8.3 \pm 1.9^{*}$ & $1.5 \pm 0.3^{*}$ \\
\hline 11 & $0.0 \pm 0.0$ & $8.5 \pm 1.1 *$ & $8.1 \pm 1.5^{*}$ & $0.0 \pm 0.0^{\circ} \dagger$ \\
\hline 30 & $0.0 \pm 0.0$ & $4.7 \pm 0.2$ *t? & $4.4 \pm 0.3^{\text {* }}$ & $0.0 \pm 0.0^{\circ}$ \\
\hline \multicolumn{5}{|c|}{ Reg. Tub. } \\
\hline 4 & $0.0 \pm 0.0$ & $0.0 \pm 0.0$ & $0.0 \pm 0.0$ & $1.2 \pm 0.2 *^{\circ}$ \\
\hline 7 & $0.0 \pm 0.0$ & $0.0 \pm 0.0$ & $0.0 \pm 0.0$ & $2.7 \pm 0.2 * \%$ \\
\hline 11 & $0.0 \pm 0.0$ & $0.0 \pm 0.0$ & $0.0 \pm 0.0$ & $7.5 \pm 1.6^{* 0 * \dagger}$ \\
\hline 30 & $0.0 \pm 0.0$ & $1.4 \pm 0.2 *$ *t॰ & $1.6 \pm 0.3^{*+t_{\bullet}}$ & $7.4 \pm 2.9^{*}$ \\
\hline \multicolumn{5}{|c|}{ Mitosis } \\
\hline 4 & $0.0 \pm 0.0$ & $0.0 \pm 0.0$ & $0.0 \pm 0.0$ & $2.2 \pm 0.8^{*}$ \\
\hline 7 & $0.0 \pm 0.0$ & $0.0 \pm 0.0$ & $0.0 \pm 0.0$ & $3.7 \pm 0.2 *^{\circ \ddagger}$ \\
\hline 11 & $0.0 \pm 0.0)$ & $1.7 \pm 0.2^{* \star \dagger}$ & $1.5 \pm 0.3^{* \star \dagger}$ & $4.5 \pm 0.3^{\circ}+\dagger$ \\
\hline 30 & $0.0 \pm 0.0$ & $1.7 \pm 0.2 * 末 \dagger$ & $1.5 \pm 0.2 * \hbar \dagger$ & $4.9 \pm 0.9^{\circ}+\dagger$ \\
\hline \multicolumn{5}{|c|}{ Solid Sheets } \\
\hline 4 & $0.0 \pm 0.0$ & $0.0 \pm 0.0$ & $0.0 \pm 0.0$ & $2.8 \pm 0.8^{\circ}$ \\
\hline 7 & $0.0 \pm 0.0$ & $0.0 \pm 0.0$ & $0.0 \pm 0.0$ & $4.8 \pm 0.6^{* \%}$ \\
\hline 11 & $0.0 \pm 0.0$ & $0.0 \pm 0.0$ & $0.0 \pm 0.0$ & $5.7 \pm 0.5 *$ \\
\hline 30 & $0.0 \pm 0.0$ & $1.3 \pm 0.2$ * *1\% & $1.4 \pm 0.4^{*}$ & $6.9 \pm 2.8 * \%$ \\
\hline
\end{tabular}

Int. Fibrosis

\begin{tabular}{|c|c|c|c|c|}
\hline 4 & $0.0 \pm 0.0$ & $0.0 \pm 0.0$ & $0.0 \pm 0.0$ & $0.0 \pm 0.0$ \\
\hline 7 & $0.0 \pm 0.0)$ & $23.7 \pm 0.91 * \sharp$ & $23.1 \pm 1.4^{* \ddagger}$ & $4.6 \pm 0.3 *^{\circ}$ \\
\hline 11 & $0.0 \pm 0.0$ & $34.2 \pm 1.3^{*{ }^{*}}$ & $32.8 \pm 2.3^{* * t \dagger}$ & $11.9 \pm 1.8^{*{ }^{* 0} \dagger}$ \\
\hline 30 & $0.0 \pm 0.0)$ & $47.6 \pm 2.6^{\text {*tio }}$ & $43.7 \pm 2.7$ *tक & 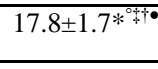 \\
\hline \multicolumn{5}{|c|}{ Atrophic Tub. } \\
\hline 4 & $0.0 \pm 0.0$ & $13.3 \pm 2.3^{*}$ & $12.5 \pm 1.4^{*}$ & $6.5 \pm 0.3^{*}$ \\
\hline 7 & $0.0 \pm 0.0$ & $12.7 \pm 1.2 *$ & $12.5 \pm 1.3^{*}$ & $4.7 \pm 0.4 *^{* \dagger}$ \\
\hline 11 & $0.0 \pm 0.0$ & $12.4 \pm 0.8^{*}$ & $12.3 \pm 0.6^{*}$ & $3.8 \pm 1.8 * \%$ \\
\hline 30 & $0.0 \pm 0.0$ & $4.4 \pm 0.2 *$ * & $4.6 \pm 0.2 *{ }^{*}$ & $2.8 \pm 0.6^{*}+7$ \\
\hline
\end{tabular}

Significant difference compared to corresponding $*$ control, ${ }^{\circ}$ cisplatin groups \&

Significant difference compared to intragroup day $4^{\star}$, day $7^{\dagger}$, day $11^{\bullet}$ by Kruskal-Wallis test at $\mathrm{P} \leq 0.05$ 


\section{Day 4:}

Sections taken from cisplatin-injected rats (Group II) and cisplatininjected rats treated with culture media through tail vein (Group III) after 4 days revealed marked degenerative changes mainly in OSOM. It varied from tubular cell vacuolar degeneration, up to complete tubular necrosis with apoptosis and shedding of tubular cells in about $90 \%$ of the tubules. Mild regenerative changes were also detected in OSOM in the form of some regenerating tubules (5\%) lined by large cells with prominent nucleoli and with occasional mitotic figures. No solid sheets were detected.

In ADMSCs injected group VI, regenerative changes were markedly detected in the OSOM and ISOM in the form of many regenerating tubules (70-80\%) lined by large cells with large hyperchromatic active nuclei with few solid sheets (less than 1/20 HPF) .

\section{Day 7:}

Sections from cisplatin injected (Group II) and cisplatin-injected rats treated with culture media through tail vein (Group III) on $7^{\text {th }}$ day showed pathological features mainly in the OSOM in the form of combined degenerative and regenerative changes. The degenerative changes predominated representing about $90 \%$ of all studied fields in this group. They varied from tubular cell vacuolar degeneration up to complete tubular necrosis with pyknosis and shedding of tubular cells. The regenerative changes detected in about $20 \%$ of all fields examined in the group, varied from tubular cell enlargement, mitosis and interstitial solid sheet formation.

Sections obtained from cisplatin-injected rats and ADMSCs (Group VI) sacrificed on the $7^{\text {th }}$ day showed less marked degenerative changes in OSOM. The degenerative changes varied from tubular cell vacuolar degeneration, up to complete tubular necrosis with apoptosis and shedding of tubular cells in about $60-70 \%$ of the tubules.

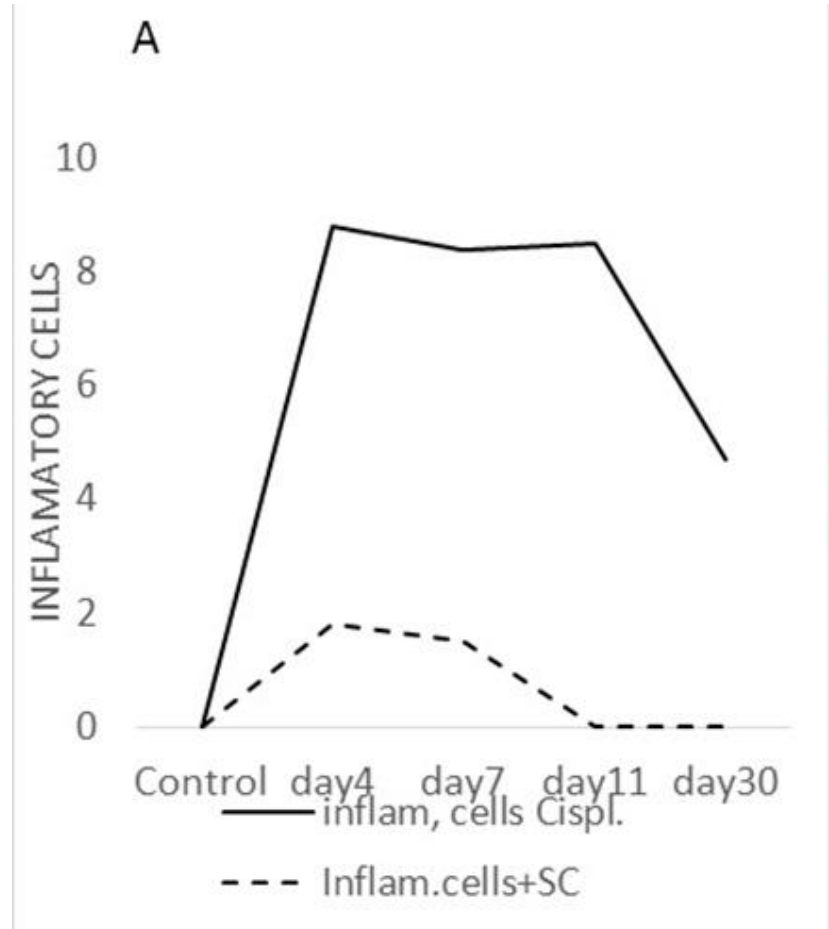

Regenerative changes detected in both outer and inner medulla were in the form of many interstitial solid sheets (12/10 HPF) and tubules lined by large cells with prominent nucleoli with occasional mitosis.

Day 11:

Kidney sections obtained from cisplatin-injected rats (Group II) and cisplatin-injected rats injected with culture media through tail vein (Group III) on the $11^{\text {th }}$ day revealed that the degenerative changes were more marked. The degenerative changes varied from tubular cell vacuolar degeneration, upto complete tubular necrosis with apoptosis and shedding of tubular cells in more than $80-90 \%$ of the tubules. In addition, there was mild interstitial round cell infiltrate. Regenerative changes were also detected and varied from tubular cell enlargement with regenerative atypia, mitosis and interstitial solid sheets $(5 / 10 \mathrm{HPF})$.

Kidney sections obtained from cisplatin-injected rats treated with ADMSCs via tail vein (Group VI) and sacrified on the $11^{\text {th }}$ day revealed necrotic tubules (about 1 tubule /HPFs) with epithelial shedding and tubular dilatation. Regenerative changes were detected in the form of solid sheets having prominent bulging nuclei (about $1 / 10 \mathrm{HPFs}$ ), mitosis (less than 1/10HPFs) and regenerating tubules were detected in one rat of the group. The interstitium was the seat of focal round cell infiltration in one rat.

\section{Day 30:}

Sections obtained on day 30 from cisplatin-injected rats (Group II) and cisplatin injected and treated with culture media through tail vein (Group III) revealed occasional regenerating large tubules in the OSOM lined by large cells with prominent nucleoli and occasional mitotic figures (1/10HPFs). There was mild peritubular and perivascular fibrosis (about 5-10\% of all fields).

Sections from kidney samples obtained from cisplatin-injected rats

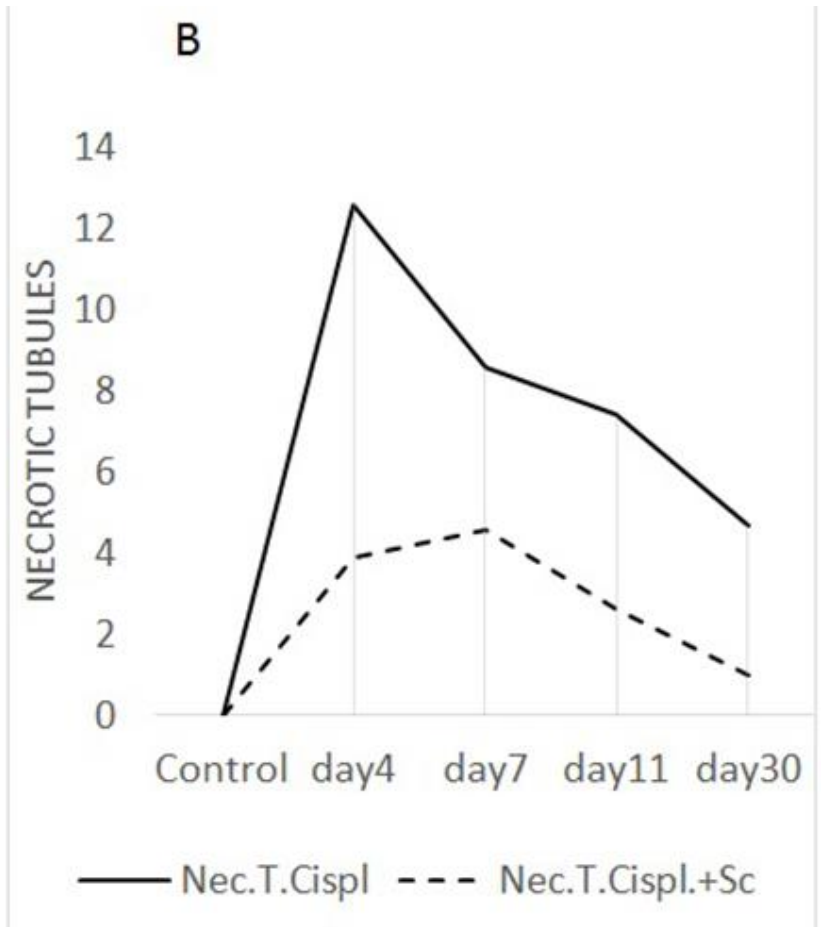

Figure 8: ADMSCs protective effect for renal tubules from cisplatin induced AKI at different time intervals. Histological changes observed in kidney tissue samples at different time intervals identified the variation in (A) inflammatory cell infiltration, (B) Necrotic tubules. 
treated with ADMSCs via tail vein (Group VI) and sacrificed on the $30^{\text {th }}$ day showed significantly less chronicity in regard to the tubular atrophy and the renal fibrosis, when compared with the cisplatin groups. The effect of ADMSCs on renal structure in term of inflammatory cell infiltration and on the necrotic tubules indicate their long-term protective activity (Figure $8 \mathrm{~A} \& \mathrm{~B}$ ).

\section{Discussion}

Several human malignancies are largely managed with cisplatin. However, in the setting of nephrotoxicity, which is one of the serious side effects of cisplatin, its clinical use as a chemotherapeutic agent is largely limited. Cisplatin acts on multiple cellular targets and hence, blocking its effect on a single target may only offer partial protection against nephrotoxicity ${ }^{[1]}$.

Although the clinical management of AKI patients has significantly improved in recent years, we still lack specific therapies to enhance kidney repair. Recovery after acute injury is critical for patient morbidity and mortality in the hospital setting ${ }^{[16]}$. The emerging field of regenerative medicine is progressing rapidly and supported by a large number of studies which have demonstrated the capacity of stem cells to substitute for the damaged or lost differentiated cells in various organs and tissues ${ }^{[17-22]}$.

Few studies have discussed the use of cord blood and bone marrow MSCs for the management of AKI models ${ }^{[23-25]}$. In addition, the ability of adipose tissue derived stromal cells to ameliorate the AKI induced via cisplatin has been reported ${ }^{[26]}$.

Reviewing the literature, some published studies have reported the impact of MSCs on cisplatin induced $\mathrm{AKI}^{[7-9]}$. Shaohua and Dongcheng's study in $2013^{[7]}$ was based on rat BMMSCs, while Weique et al. 2015 ${ }^{[8]}$ and Kim et al. 2015 ${ }^{[9]}$ studies were based on human ADMSCs. The latter reported that ADMSCs exert a paracrine protective effect on cisplatin nephrotoxicity and suggested that human ADMSCs might be a new therapeutic approach for patients with acute kidney injury. Many points distinguish our work from these studies as follows; (1) all of the previous studies evaluated the protective effect of MSCs only for a short duration (only the acute effect for 3 to 5 days of cisplatin induced AKI). While our work, in addition to evaluating the short duration effect, has evaluated the long term protective effect ( the chronic effect) (2) the sample size used in those studies was noticeably small while our work included a large sample size, (3) these studies identified renal protective effect of MSCs only using biochemical renal function analyses and renal histology. An important parameter in our work, was the assessment of the oxidative stress in kidney tissue for evaluating the ADMSCs' protective effect (4) In addition, through scoring of different histopathological findings, this study tried to evaluate both the protective and the regenerative activities of ADMSCs by correlating them to the biochemical parameters.

The damaging effect of cisplatin on the kidney comprises of complex interrelated sequence of events eventually resulting in both apoptosis and necrosis of the renal cells ${ }^{[1]}$. Thus, an ideal modality to manage cisplatin nephrotoxicity should work by multiple mechanisms.

The aim of our study was to address the role of ADMSCs in AKI secondary to cisplatin administration where 80 rats were divided into four equal groups: positive control (cisplatin injected); negative control (saline injected group); (cisplatin injected and culture media treated) and (cisplatin injected and ADMSCs treated) group.

Moreover, in each group, rats' were subgrouped based on day of sacrifice on day 4, day 7, day 11 and day 30 to study the evolution of
ADMSCs activity on the acute injury, regenerative activity and the tissue chronicity events induced by cisplatin separately. In our study, the use of ADMSCs was capable of ameliorating renal dysfunction; as demonstrated by improvement of serum creatinine, creatinine clearance and improvement of the histological indices of injury in the renal cortex and outer medulla.

ADMSCs rapidly ameliorated and protected the kidneys in-group IV starting from day 4 (Figure 8). Regeneration of the tubular cells under the influence of ADMSCs cannot explain the recovery. There was markedly less necrotic changes in spite of only 1/20 HPF interstitial solid sheets. The possible explanation could be through the paracrine effect of the ADMSCs as previously demonstrated by numerous studies, which have shown that organ protection by administered stem cells is primarily due to paracrine mechanisms rather than the replacement of damaged cells by differentiated stem cells $^{[27-31]}$.

Other workers studying the ADMSCs role in cisplatin induced $\mathrm{AKI}^{[8,9]}$ have reached to the same conclusion. They suggested that ADMSCs might exert beneficial paracrine actions on the injured kidney by releasing biologically active factors where they used a culture media from cultured ADMSCs. Co-culturing ADMSCs or culture media of ADMSCs with proximal renal tubular cells, protected cultured human renal proximal tubular cells from cisplatin toxicity ${ }^{[25]}$.

Reactive oxygen species are important mediators exerting toxic effects on various organs including the kidney where Chin et al. [29] concluded that ADMSCs administration minimized the AKI through suppression of the inflammatory response and the oxidative stress. This possible mechanism of renal protection was also demonstrated in our study where the use of ADMSCs partially suppressed oxidative stress and lipid peroxidation as reflected by decrease in the level of Malondialdehyde. Concomitantly ADMSCs increased superoxide dismutase and glutathione reductase in the renal tissue.

Our data indicate the ability of ADMSCs to protect against an advanced acute tubular necrosis as that detected in the control positive group of cisplatin. In addition, in spite of an early single dose of ADMSCs, this group of rats had developed a significant regenerative activity extending until day 30 with limited fibrotic activity. These observations raise the importance of latter booster doses of ADMSCs.

Interestingly, ADMSCs treated group of rats' showed highly important parallel improvement in renal tissue oxidative stress markers with the acute injury morphological scores (Table2; Figure 6B) better than with the creatinine clearance (Figure 6A) when compared with the control positive group. This improvement was of many folds with GSH as compared with the cisplatin group, indicating a key role of GSH in protecting against cisplatin induced acute tubular necrosis. The latter finding raises the question about the molecular mechanism of ADMSCs in promoting GSH. In addition, the early-administered single dose of ADMSCs seems to exercise long-term beneficial activity. This observation needs further exploration in regard to the probable interaction between the exogenously administered stem cells and the endogenous stem cells.

In conclusion, ADMSCs represent an easy practical source of stem cells. They have both protective and regenerative activities with consequent limitation of the development of renal fibrosis on top of the cisplatin induced acute tubular necrosis. Proposed anti-oxidative activity mediated through GSH activity promotion has an important role. The chronicity of the histopathological scoring indicates a promising advantage for a late booster dose of ADMSCs. 


\section{References}

1. Pabla N, Dong Z. Cisplatin nephrotoxicity: mechanisms and renoprotective strategies. Kidney Int 2008; 73 (9): 994-1007.

2. Herrera MB, Bussolati B, Bruno S, Fonsato V, Romanazzi GM, Camussi G. Mesenchymal stem cells contribute to the renal repair of acute tubular epithelial injury. Int J Mol Med 2004; 14 (6): 1035-41.

3. Kunter U, Rong S, Djuric Z, Boor P, Müller-Newen G, Yu D, Floege J. Transplanted mesenchymal stem cells accelerate glomerular healing in experimental glomerulonephritis. J Am Soc Nephrol 2006; 17 (8): 2202-12.

4. Ling SI Y, LiZhao Y, Hao HJ, BingFu X, Han WD. MSCs: Biological characteristics, clinical applications and their outstanding concerns. Ageing Research Reviews 2011; 10(1): 93-103.

5. Bassi G, Pacelli L, Carusone R, ZanoncelloJasmina, Krampera M. Adipose-derived stromal cells (ASCs). Transfusion and Apheresis Science 2012; 47 (2): 193-8.

6. Zuk PA. Stem cell research has only just begun. Science 2001; 293(5528):211-12.

7. Shaohua QI, Dongcheng WU. Bone marrow-derived mesenchymal stem cells protect against cisplatin-induced acute kidney injury in rats by inhibiting cell apoptosis. International Journal of Molecular Medicine 2013; 32 (6): 1262-72.

8. Weiqi Yao, Qinyong HU, Yuhong MA, Wenping Xiong, Tingting WU, Jun CAO, Dongcheng WU. Human adipose-derived mesenchymal stem cells repair cisplatininduced acute kidney injury through anti-apoptotic pathways. Exp Ther Med. 2015;10(2):468-476.

9. Kim JH, Park DJ, Yun JC, Jung MH, Yeo HD, Kim HJ, Kim DW, Yang JI, Lee GW, Jeong SH, Roh GS, Chang $\mathrm{SH}$. Human adipose tissue-derived mesenchymal stem cells protect kidneys from cisplatin nephrotoxicityin rats. Am J Physiol Renal Physiol. 2012; 1; 302(9):F1141-50.

10. Bunnell BA, Flaat M, Gagliardi C, Patel B, Ripoll C. Adipose-derived stem cells: isolation, expansion and differentiation. Methods 2008; 45(2):115-20.

11. Phinney DG, Kopen G, Isaacson RL \&Prockop DJ. Plastic adherent stromal cells from the bone marrow of commonly used strains of inbred mice: variations in yield, growth, and differentiation. J Cell Biochem 1999; 72(4):570-85.

12. Rombouts WJ, Ploemacher RE. Primary murine MSC show highly efficient homing to the bone marrow but lose homing ability following culture. Leukemia 2003; 17(1): 160-70.

13. Peister A, Mellad JA, Larson BL, Hall BM, Gibson LF, Prockop DJ. Adult stem cells from bone marrow (MSCs) isolated from different strains of inbred mice vary in surface epitopes, rates of proliferation, and differentiation potential. Blood 2004; 103(5): 1662-68.

14. Collins TJ. Image $\mathbf{J}$ for microscopy. BioTechniques 2007; 43 (1 Suppl): 25-30.

15. Van Roeyen CR, Ostendorf T, Denecke B, Bokemeyer D, Behrmann I, Strutz F, Lichenstein HS, LaRochelle WJ, Pena CE, Chaudhuri A, Floege J. Biological responses to PDGF-BB versus PDGF-DD in human mesangial cells. Kidney Int. 2006; 69(8) 1393-1402.

16. Bussolati B, Tetta C, Camussi G. Contribution of Stem Cells to Kidney Repair Am J Nephrol 2008;28(5):813-22.

17. Donovan $\mathrm{P}$, Gearhart J. The end of the beginning for pluripotent stem cells. Nature 2001; 414: 92-97.
18. Goodell M. Stem-cell 'plasticity': befuddled by the muddle. Curr Opin Hematol 2003; 10(3): 208-13.

19. Herzog E, Chai L, Krause D. Plasticity of marrow-derived stem cells. Blood 2003; 102(10): 3483-93.

20. Weissman I. Stem cells: units of development, units of regeneration, and units of evolution. Cell 2000; 100(1): 157-68.

21. Erpicum P, Detry O, Weekers L, Bonvoisin C, Lechanteur $\mathrm{C}$, Briquet A, Yves Beguin Y, Krzesinski J-M, Jouret F. Mesenchymal stromal cell therapy in conditions of renal ischaemia/reperfusion. Nephrol Dial Transplant. 2014; 29(8):1487-93.

22. Zou X, Zhang G, Cheng Z, Yin D, Du T, Ju G, Miao S, Liu G, Lu M, Zhu Y. Microvesicles derived from human Wharton's Jelly: mesenchymal stromal cells ameliorate renal ischemia-reperfusion injury in rats by suppressing CX3CL1. Stem Cell Research \& Therapy 2014, 5(2):4053.

23. Morigi M, Imberti B, Zoja C, Corna D, Tomasoni S, Abbate M, Rottoli D, Angioletti S, Benigni A, Perico N, Alison M, Remuzzi G. Mesenchymal stem cells are renotropic, helping to repair the kidney and improve function in acute renal failure. J Am Soc Nephrol 2004; 15(7): 1794-1804.

24. Morigi M, Introna M, Imberti B, Corna D, Abbate M, Rota C, Rottoli D, Benigni A, Perico N, Zoja C, Rambaldi A, Remuzzi A, Remuzzi G. Human bone marrowmesenchymal stem cells accelerate recovery of acute renal injury and prolong survival in mice. Stem Cells 2008; 26(8): 2075-82.

25. Morigi M, Rota C, Montemurro T, Montelatici E, Lo Cicero V, Imberti B, Abbate M, Zoja C, Cassis P, Longaretti L, Rebulla P, Introna M, Capelli C, Benigni A, Remuzzi G, Lazzari L. Life-sparing effect of human cord blood-mesenchymal stem cells in experimental acute kidney injury. Stem Cells 2010; 28(3): 513-22.

26. Bi B, Schmitt R, Israilova M, Nishio H, Cantley LG. Stromal cells protect against acute tubular injury via an endocrine effect. Am Soc Nephrol 2007; 18(9): 2486-96.

27. Gnecchi M, He H, Liang OD, Melo LG, Morello F, Mu H, Noiseux N, Zhang L, Pratt RE, Ingwall JS, Dzau VJ. Paracrine action accounts for marked protection of ischemic heart by Akt-modified mesenchymal stem cells. Nat Med 2005; 11(4): 367-68.

28. Kinnaird T, Stabile E, Burnett MS, Lee CW, Barr S, Fuchs S, Epstein SE. Marrow-derived stromal cells express genes encoding a broad spectrum of arteriogenic cytokines and promote in vitro and in vivo arteriogenesis through paracrine mechanisms. Circ Res 2004; 94(5): 678-85.

29. Kinnaird T, Stabile E, Burnett MS, Shou M, Lee CW, Barr S, Fuchs S, Epstein SE. Local delivery of marrowderived stromal cells augments collateral perfusion through paracrine mechanisms. Circulation 2004; 109(12): 1543-49.

30. Togel F, Hu Z, Weiss K, Isaac J, Lange C, Westenfelder C. Administered mesenchymal stem cells protect against ischemic acute renal failure through differentiationindependent mechanisms. Am J Physiol Renal Physiol 2005; 289(1): F29-30.

31. Chen YT, Sun CK, Lin YC, Chang LT, Chen YL, Tsai TH, Chung SY, Chua S, Kao YH, Yen CH, Shao PL, Chang KC, Leu S, Yip HK. Adipose-derived mesenchymal stem cell protects kidneys against ischemiareperfusion injury through suppressing oxidative stress and inflammatory reaction. J Transl Med. 2011; 9:51. 


$\begin{array}{ll}\text { Abbreviations } & \\ \text { h-ADMSCs } & \text { : Human-Adipose Derived Mesenchymal Stem Cells } \\ \text { AKI } & \text { : Acute Kidney Injury } \\ \text { BUN } & \text { : Blood Urea Nitrogen } \\ \text { MDA } & \text { : Malondialdehyde } \\ \text { SOD } & \text { : Superoxide dismutase } \\ \text { GSH } & \text { : Reduced Glutathione } \\ \text { PBS } & \text { : Phosphate-Buffered Saline } \\ \text { DMEM } & \text { : Dulbecco's Modified Eagle's Medium } \\ \text { FBS } & \text { : Fetal Bovine Serum } \\ \text { FACS } & \text { : Fluorescence-Activated Cell Sorting } \\ \text { CFU-F } & : \text { Colony Forming Unit-Fibroblast } \\ \text { RT-PCR } & \text { : Real-Time quantitative Reverse Transcriptase-Polymerase Chain Reaction } \\ \text { ALBP } & \text { : Adipocyte Lipid-Binding Protein } \\ \text { OSOM } & \text { : Outer Strip of Outer Medulla } \\ \text { ISOM } & \text { : Inner Strip of Outer Medulla }\end{array}$

\section{Potential Conflicts of Interests}

None

\section{Acknowledgements}

This work was supported by Science and Technology Development Fund (STDF), grant number 1061, Ministry of Scientific Research, Egypt.

\section{Corresponding Author}

Mohamed-Ahdy A.A. Saad, Faculty of Medicine, Mansoura University, Mansoura, Egypt; E-mail: ahady2007@yahoo.com 